\title{
Linking phosphorus extraction from different types of biomass incineration ash to ash mineralogy, ash composition and chemical characteristics of various types of extraction liquids
}

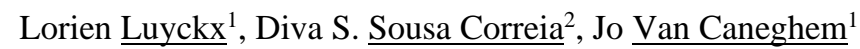 \\ ${ }^{1}$ KU Leuven, Department of Materials Engineering, Sustainable Materials Processing and Recycling (SeMPeR), Campus \\ Group T, Andreas Vesaliusstraat 13 - box 2600, 3000 Leuven, Belgium \\ ${ }^{2}$ BMC Moerdijk BV, Industrial park M349, Middenweg 36a, 4782 PM Moerdijk, The Netherlands \\ Corresponding author: Lorien Luyckx, lorien.luyckx@kuleuven.be
}

ORCID: Lorien Luyckx (0000-0002-2700-7726); Jo Van Caneghem (0000-0002-4052-1260)

\begin{abstract}
Phosphorus $(\mathrm{P})$ rich ash from biomass incineration is a potential promising alternative for non-renewable phosphate rock. This study considered the $\mathrm{P}$ recovery potential of poultry manure ash, sewage sludge ash and meat and bone meal ash through wet chemical extraction. XRD analysis showed that these three ash types had a distinct P mineralogy. If inorganic acids were used for the extraction, the P extraction efficiency was not or only slightly affected by the P mineralogy. Contrarily, for the organic acids, alkaline extraction liquid and chelating agents considered, the P extraction efficiency was highly affected by the P mineralogy, and was also affected by the elemental composition of the ash and/or the chemical characteristics of the extraction liquids. Alkaline extraction liquids showed in general low heavy metal co-extraction, in contrast to the inorganic acids. From an economic point of view, of all extraction liquids considered, sulfuric acid was the most interesting to extract $\mathrm{P}$ from all three ash types. Oxalic acid could be a more sustainable option for $\mathrm{P}$ extraction from sewage sludge ash. In addition, extraction of poultry manure ash with ethylenediaminetetraacetic acid showed a relatively high $\mathrm{P}$ extraction efficiency combined with relatively low heavy metal co-extraction.
\end{abstract}

Keywords: Heavy metal extraction; Incineration ash; Meat and bone meal; Phosphorus extraction; Poultry manure; Sewage sludge.

\section{Graphical abstract}

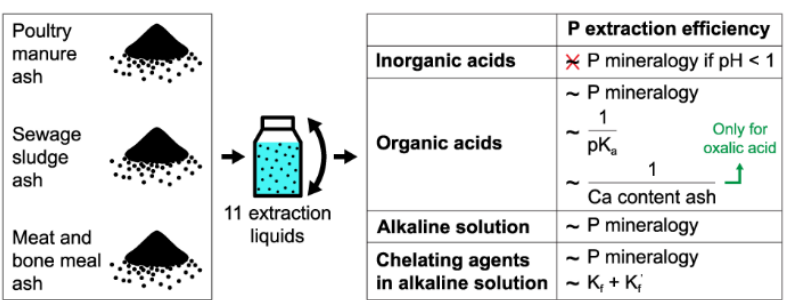

\section{Statement of novelty}

The present study is the first of its kind to evaluate and compare the efficiency of $\mathrm{P}$ and heavy metal extraction from different types of biomass ash considering various types of extraction liquids. Another novelty is the fact that the P (and heavy metal) extraction efficiency for the different types of biomass ash is linked to the ash mineralogy, elemental composition of the ash, and/or chemical characteristics of the extraction liquids.

\section{Abbreviations for biomass and ash types}

$\begin{array}{ll}\text { MBM } & \text { meat and bone meal } \\ \text { MBMA } & \text { meat and bone meal ash } \\ \text { PM } & \text { poultry manure } \\ \text { PMA } & \text { poultry manure ash } \\ \text { SS } & \text { sewage sludge } \\ \text { SSA } & \text { sewage sludge ash }\end{array}$




\section{Introduction}

Globally, each year about 20 million tonnes of phosphorus $(\mathrm{P})$ are extracted from phosphate rock to be used in fertilizers, animal feed and detergents [1-3]. However, phosphate rock is a non-renewable resource that is becoming scarce, while reserves are unevenly distributed over the world. Europe for instance, mainly depends on $\mathrm{P}$ and phosphate rock imports from other continents $[4,5]$. To avoid a $\mathrm{P}$ shortage and to reduce Europe's economic dependence, it is imperative to recover $\mathrm{P}$ from alternative sources.

After its use in different applications, a substantial part of the $\mathrm{P}$ extracted from phosphate rock eventually ends up in sewage sludge (SS) originating from wastewater treatment and in animal manure or animal by-products such as meat and bone meal (MBM) $[3,5,6]$. The application of SS as fertilizer to agricultural land is in most countries restricted or even prohibited because of its high concentrations of heavy metals and toxic organic compounds [7,8]. The latter can be destroyed by incinerating the SS. However, the major fraction of the heavy metals remains in the resulting sewage sludge ash (SSA) and can pose, depending on local legislation, a regulatory constraint for direct application of the SSA as fertilizer [9-11]. On the other hand, animal manure is widely applied as fertilizer, although it is often present in excess in areas of intensive livestock farming [12-14]. Therefore, an alternative to direct land application is incineration of the animal manure, which reduces its volume whilst part of its energy content is recovered [14-17]. The power plant of BMC Moerdijk (the Netherlands) for instance, annually converts about 420,000 tonnes of poultry manure (PM) into green energy, producing about 55,000 tonnes of poultry manure ash (PMA). This PMA contains high concentrations of the essential fertilizer nutrients $\mathrm{P}$ and $\mathrm{K}$, but its application as fertilizer is subject to legal constraints [18]. As for animal by-products, the outbreak of the mad cow disease (BSE) resulted in a ban on the use of MBM in animal feed from 2001 [13]. Since then, MBM, which has a high calorific value, is mainly mono-incinerated or co-incinerated with other waste in dedicated installations or in cement kilns $[5,13,19,20]$. One of the advantages of biomass incineration in general is that $\mathrm{P}$ is not transferred to the gas phase but is largely retained in the ash [17,21]. However, in the case of co-incineration in cement kilns, the P in the biomass is mixed with the cement components and is permanently lost for recovery $[5,10]$. The P content in SSA, animal manure ash and meat and bone meal ash (MBMA) ranges between 3\% and 20\% [15, 19, 21-23]. Therefore, these ash types are a potential promising alternative for non-renewable (low grade) phosphate rock that contains between $2 \%$ and $18 \% \mathrm{P}$ [24, 25].

Wet chemical extraction is the most proposed technique to recover $\mathrm{P}$ from incineration ash because of its high efficiency, low cost and because it is already applied on an industrial scale for $\mathrm{P}$ extraction from phosphate rock [9, 22, 26]. Various types of extraction liquids have been evaluated for $\mathrm{P}$ extraction, such as inorganic acids, organic acids, alkaline extraction liquids and chelating agents [9, 12, 22, 27-29]. A shown general disadvantage of wet chemical extraction is that heavy metals in the incineration ash are co-extracted. Subsequently, these heavy metals have to be separated from the valuable $\mathrm{P}$ by, for instance, cation exchange, $\mathrm{pH}$ adjustment or sulfide precipitation [25, 30-32]. As a consequence, an optimal extraction liquid combines a high $\mathrm{P}$ extraction efficiency with low heavy metal co-extraction, in this way reducing the downstream processing costs for heavy metal removal.

A first conclusion from a dedicated literature review was that the majority of studies on $\mathrm{P}$ recovery from incineration ash focused on only one type of incineration ash at a time. Indeed, researchers mainly focused on P recovery from SSA [e.g., $7,9,22,25,28,32]$ and to a lesser extent on P recovery from either animal manure ash [e.g., 12, 16, 26] or MBMA [e.g., $16,29]$. However, to replace the major part of $P$ that is currently extracted from phosphate rock, all different types of $P$ rich incineration ash will have to be exploited since one ash type alone cannot supply the necessary amount of $\mathrm{P}$ [6]. The literature also shows that different ash types can have a distinct mineralogy [16, 33, 34], which can influence the P recovery process. However, to the authors knowledge, the link between ash mineralogy and P extraction efficiency has not been studied in dept in the literature. The best way to do so, would be to compare the ash mineralogy and $\mathrm{P}$ extraction efficiency for different types of biomass ash. Furthermore, most studies found in the literature only considered a limited set of extraction liquids for $\mathrm{P}$ recovery from incineration ash. Yet, different extraction liquids show different $\mathrm{P}$ and heavy metal extraction efficiencies $[12,22,32]$. Finally, the extraction settings (extraction liquid concentration, liquid/solid (L/S) ratio, contact time, etc.) and properties of the considered ash types (ash composition, ash mineralogy, etc.) differ for most studies found in the literature and hence a one-on-one comparison of literature data is almost impossible. Therefore, it is important to include a broad set of extraction liquids in comparative ash extraction studies.

Given the conclusions of the literature review discussed in the previous paragraph, the overall aim of this comprehensive study was to evaluate and compare the efficiency of $\mathrm{P}$ and heavy metal extraction from PMA, SSA and MBMA using a broad set of different types of extraction liquids. The experiments were set-up and the obtained results were in the first place interpreted from an engineering perspective. Yet, where possible, an attempt was made to link, based on fundamental chemical laws, the observed differences in $\mathrm{P}$ and heavy metal extraction efficiency to the ash mineralogy, elemental composition of the ash, and/or chemical characteristics of the extraction liquids.

\section{Materials and methods}

\subsection{Chemical characterization of the different ash types}

Three different ash types were investigated in this research, i.e., PMA, SSA and MBMA. The PMA sample was obtained from the fluidized bed power plant of BMC Moerdijk (the Netherlands), where PM is incinerated at a bed temperature of $765^{\circ} \mathrm{C}$. This PMA was a mixture of ash collected at the bottom of the fluidized bed, superheater, economizer, electrostatic precipitator and baghouse filter with a mass ratio of 26:6:5:58:5, which corresponds to the ratio of total ash production. A 
detailed description of the power plant of BMC Moerdijk and the sampling locations can be consulted in previous work of the authors [18]. The SSA sample was obtained from the electrostatic precipitator of the Aquafin fluidized bed incineration plant (Belgium), where SS is incinerated at bed temperatures between 840 and $850^{\circ} \mathrm{C}$. The MBMA was prepared by incinerating MBM, received from Indaver (Belgium), for 3 hours at $850^{\circ} \mathrm{C}$ in a muffle furnace after which it was cooled to room temperature in the ambient air. The PMA and MBMA were rather inhomogeneous in particle size and were grinded to a homogeneous particle size $(<40 \mu \mathrm{m})$. The SSA consisted already of a fine homogeneous powder $(<40 \mu \mathrm{m})$. All ash samples were homogenized by thorough mixing, after which subsamples were taken for the experiments.

The three ash types were digested with a combination of aqua regia and hydrofluoric acid. The method used in this paper was based on CMA/2/II/A.3 and the European standard EN 13656:2002 [35, 36]. For the digestion, $500 \mathrm{mg}$ of dry (grinded) ash, $8 \mathrm{ml}$ aqua regia and $6 \mathrm{ml}$ hydrofluoric acid were mixed in a well-sealed $100 \mathrm{ml}$ HDPE digestion bottle. After $44 \mathrm{~h}$ of reaction and mixing in between, the content was transferred to a $100 \mathrm{ml}$ PP volumetric flask containing about $5.6 \mathrm{~g}$ boric acid and diluted to the mark. This solution was further filtered over a syringe filter $(0.45 \mu \mathrm{m})$ and analyzed for $\mathrm{Al}, \mathrm{Ca}, \mathrm{Cd}$, $\mathrm{Cr}, \mathrm{Cu}, \mathrm{Fe}, \mathrm{K}, \mathrm{Mg}, \mathrm{Na}, \mathrm{Ni}, \mathrm{P}, \mathrm{Pb}, \mathrm{S}, \mathrm{Si}$ and $\mathrm{Zn}$ by Inductively Coupled Plasma Optical Emission Spectroscopy (ICP-OES) (Varian 720- ES ICP-OES). No glassware was used for digestion and dilution. It should be noted that in this work the digestion was not microwave or temperature assisted. Previous experiments performed by the authors comparing microwave assisted digestion and the digestion described above indicated that for the ash types studied in this work similar composition data was obtained through both digestion methods.

To determine the ash mineralogy in the crystalline phase, the three ash types were mechanically grinded in the presence of ethanol and a corundum internal standard. Next, they were analyzed by quantitative X-ray diffraction (XRD) (D8 Bruker) with $\mathrm{Cu} \mathrm{K}_{\alpha}$ radiation and the data obtained was refined based on the Rietveld method.

\subsection{Extraction experiments}

Eleven different extraction liquids were selected based on a literature review and own experience [7, 9, 29, 32, 37-42, $12,16,21,22,25-28]$. The different extraction liquids were tested at a concentration of $0.5 \mathrm{~N}$, an L/S ratio of $50 \mathrm{ml} / \mathrm{g}$ ash and a contact time of $2 \mathrm{~h}$ for all three ash types. The same concentration $(0.5 \mathrm{~N})$ was used for all extraction liquids so that equivalent weights of reactive units $\left(\mathrm{H}^{+}\right.$or $\left.\mathrm{OH}^{-}\right)$were present to obtain similar extraction conditions (see the first paragraph of section 3.2 for more detailed information on the influence of the reactive units on the $\mathrm{P}$ extraction efficiency). However, extraction liquids with equivalent weights of reactive units will not necessarily release the same amount of reactive units into solution to react with the P. For instance, weak acids do not completely dissociate in aqueous solutions, resulting in a lower amount of released reactive units $\left(\mathrm{H}^{+}\right)$, which is reflected in higher $\mathrm{pH}$ values. In this way, the $\mathrm{pH}$ in the extraction experiments was intrinsically determined by the type and concentration of the extraction liquid and the specific ash type. The obtained $\mathrm{pH}$ was thus not actively controlled and was therefore different for the different extraction liquids and ash types.

The considered extraction liquids consisted of three inorganic acids, i.e., sulfuric acid, hydrochloric acid and nitric acid, and five organic acids, i.e., acetic acid, citric acid, formic acid, gluconic acid and oxalic acid. The organic acids provided both an acid and complexing extraction environment [12]. Furthermore, one alkaline extraction liquid, i.e., sodium hydroxide, and two chelating agents, i.e., ethylenediaminetetraacetic acid (EDTA) and nitrilotriacetic acid (NTA) were considered. Both chelating agents were dissolved in a sodium hydroxide solution, since their solubility in alkaline solutions is much higher than in water. For this, a $0.5 \mathrm{~N}$ sodium hydroxide solution was used, allowing to compare the results of the chelating agents with the results of the pure $0.5 \mathrm{~N}$ sodium hydroxide solution.

The extraction experiments were carried out at room temperature and all glassware was first rinsed with a $3 \%$ nitric acid solution. A well-sealed $50 \mathrm{ml}$ PP falcon tube (HDPE flat cap) with $500 \mathrm{mg}$ of dry (grinded) ash and $25 \mathrm{ml}$ extraction liquid with a concentration of $0.5 \mathrm{~N}$ was placed horizontally on a reciprocating shaker (Heidolph Promax 2020) for $2 \mathrm{~h}$ at maximum speed $(400 \mathrm{rpm})$. For each run, the $\mathrm{pH}$ of the extraction liquid was measured at the start and at the end of the extraction procedure (SenTix 21 electrode). Next, the solutions were filtered $(0.45 \mu \mathrm{m})$ and analyzed for $\mathrm{Cd}, \mathrm{Cr}, \mathrm{Cu}, \mathrm{Ni}, \mathrm{P}$, $\mathrm{Pb}$ and $\mathrm{Zn}$ by ICP-OES (Varian 720-ES ICP-OES). The extraction efficiency was calculated as the amount of element extracted according to Eq. (1):

Extraction efficiency $(\%)=\frac{\text { Element extracted }(\% \text { of DM) }}{\text { Element in ash }(\% \text { of DM })} \times 100 \%$

\subsection{Selection of the most optimal extraction liquid}

The selection of the most optimal extraction liquid was based on the extraction efficiencies of both $\mathrm{P}$ and heavy metals. First, a high $\mathrm{P}$ extraction efficiency was desirable to recover as much $\mathrm{P}$ as possible for application as an essential nutrient in fertilizers. Moreover, a high $\mathrm{P}$ extraction efficiency results in a low $\mathrm{P}$ concentration in the solid extraction residue, which is desirable when using this solid residue as building material or in cement production [18].

Second, the extraction efficiencies of heavy metals had to be as low as possible to limit the costs of further processing the $\mathrm{P}$ extract to a final $\mathrm{P}$ fertilizer product that complies with legal limit values for heavy metals in fertilizers. This research focused on the heavy metals $\mathrm{Cd}, \mathrm{Cr}, \mathrm{Cu}, \mathrm{Ni}, \mathrm{Pb}$ and $\mathrm{Zn}$ for which limit values apply in the Flemish legislation for the use of waste materials as a fertilizer (VLAREMA, Annex 2.3.1.A) [43]. It should be noted that the concentration limit values for heavy metals laid down in the Flemish legislation do not directly apply to the extraction liquid but to the final fertilizer 
product. However, they serve as a relevant selection base since co-extraction of these heavy metals causes extra purification costs to prevent that they remain in the final fertilizer product.

\subsection{Statistical analysis}

Digestions and extraction experiments were performed in triplicate with subsamples from the same ash sample. Average values and standard deviations were determined to assess statistical significance of trends and differences.

\section{Results and discussion}

\subsection{Chemical characterization of the different ash types}

Table 1 gives the concentrations of the major elements (\% of dry matter (DM)) and of the heavy metals of concern (mg/kg DM) in the PMA, SSA and MBMA. The average P concentration in these three ash types was $6.11 \%, 6.99 \%$ and $13.49 \%$ of DM, respectively, which is comparable to the P content in (low grade) phosphate rock $(2 \%-18 \%)$ [2, 24, 25]. Similar P concentrations were found in literature for these ash types: 4\% - 11\% P in PMA [15, 16, 23, 33], 4\% - 12\% P in SSA $[3,9,21,22,25,39]$, and 8\% - 20\% P in MBMA [16, 19, 21, 23].

The SSA showed higher levels of Al, Fe and Si compared to the PMA and MBMA (see Table 1). This is due to the presence of sand and the addition of $\mathrm{Fe}$ or $\mathrm{Al}$ containing chemicals for $\mathrm{P}$ precipitation during wastewater treatment. On the other hand, the PMA and MBMA showed higher concentrations of Ca compared to the SSA. The highest concentrations of heavy metals $(\mathrm{Cd}, \mathrm{Cr}, \mathrm{Cu}, \mathrm{Ni}, \mathrm{Pb}$ and $\mathrm{Zn}$ ) were found in the SSA, while the MBMA was generally the least contaminated of the tree ash types (see Table 1).

Table 2 gives the results of the XRD analysis of the PMA, SSA and MBMA. This table shows that about $22 \%$ of the MBMA consisted of amorphous material from which the mineralogy could not be determined, whereas the share of amorphous material was much higher for SSA (about 36\%) and PMA (about 48\%). The main crystalline minerals present in the PMA were apatite $\left(\mathrm{Ca}_{5}\left(\mathrm{PO}_{4}\right)_{3}(\mathrm{OH}, \mathrm{Cl}, \mathrm{F})\right)$, arcanite $\left(\mathrm{K}_{2} \mathrm{SO}_{4}\right)$, quartz $\left(\mathrm{SiO}_{2}\right)$, calcite $\left(\mathrm{CaCO}_{3}\right)$ and $\mathrm{KNaCa}$-phosphate $\left(\mathrm{KNaCa}_{2}\left(\mathrm{PO}_{4}\right)_{2}\right)$. The SSA mainly contained quartz, whitlockite $\left(\mathrm{Ca} 9(\mathrm{Mg}, \mathrm{Fe})\left(\mathrm{PO}_{4}\right)_{6}\left(\mathrm{PO}_{3} \mathrm{OH}\right)\right)$, hematite $\left(\mathrm{Fe}_{2} \mathrm{O}_{3}\right)$ and magnetite $\left(\mathrm{Fe}_{3} \mathrm{O}_{4}\right)$ in the crystalline phase. The crystalline phase in the MBMA mainly consisted of apatite, buchwaldite $\left(\mathrm{NaCaPO}_{4}\right)$ and lime $(\mathrm{CaO})$. The amount of $\mathrm{P}$ bound in the different crystalline minerals and in the amorphous phase was calculated based on the $\mathrm{P}$ and phosphates content in the crystalline phase in the three ash types (Table 1 and Table 2, respectively). It was found that $52 \%$ of total $\mathrm{P}$ in the PMA was bound in the amorphous phase, whereas $30 \%$ of total $\mathrm{P}$ was bound as apatite and $18 \%$ of total $\mathrm{P}$ was bound as KNaCa-phosphate. For SSA, 59\% of total P was bound in the amorphous phase, $39 \%$ of total $\mathrm{P}$ was bound as whitlockite and $2 \%$ of total $\mathrm{P}$ was bound as apatite. For MBMA, $67 \%$ of total P was bound as apatite, $18 \%$ of total $\mathrm{P}$ was bound as buchwaldite and $15 \%$ of total $\mathrm{P}$ was bound in the amorphous phase. 
Table 1 Average elemental composition of the PMA, SSA and MBMA \pm standard deviation (\% of DM or mg/kg DM) $(\mathrm{n}=3$, subsamples from the same sample).

\begin{tabular}{|c|c|c|c|c|}
\hline & & PMA & SSA & MBMA \\
\hline $\mathrm{Al}$ & $(\%$ of $\mathrm{DM})$ & $\begin{array}{c}0.56 \\
\pm 0.01\end{array}$ & $\begin{array}{c}5.99 \\
\pm 0.06\end{array}$ & $\begin{array}{c}0.17 \\
\pm 0.01\end{array}$ \\
\hline $\mathrm{Ca}$ & $(\%$ of DM) & $\begin{array}{r}21.12 \\
\pm 0.30\end{array}$ & $\begin{array}{c}6.64 \\
\pm 0.02\end{array}$ & $\begin{array}{c}33.63 \\
\pm 0.14\end{array}$ \\
\hline $\mathrm{Fe}$ & $(\%$ of DM) & $\begin{array}{c}0.36 \\
\pm 0.01\end{array}$ & $\begin{array}{c}9.92 \\
\pm 0.05\end{array}$ & $\begin{array}{c}1.67 \\
\pm 0.03\end{array}$ \\
\hline K & $(\%$ of $\mathrm{DM})$ & $\begin{array}{c}7.11 \\
\pm 0.17\end{array}$ & $\begin{array}{c}1.67 \\
\pm 0.01\end{array}$ & $\begin{array}{c}3.03 \\
\pm 0.04\end{array}$ \\
\hline $\mathrm{Mg}$ & $(\%$ of $\mathrm{DM})$ & $\begin{array}{c}2.81 \\
\pm 0.02\end{array}$ & $\begin{array}{c}1.21 \\
\pm 0.003\end{array}$ & $\begin{array}{c}1.24 \\
\pm 0.01\end{array}$ \\
\hline $\mathrm{Na}$ & $(\%$ of DM) & $\begin{array}{c}1.33 \\
\pm 0.004\end{array}$ & $\begin{array}{c}0.54 \\
\pm 0.005\end{array}$ & $\begin{array}{c}2.28 \\
\pm 0.01\end{array}$ \\
\hline $\mathrm{P}$ & $(\%$ of $\mathrm{DM})$ & $\begin{array}{c}6.11 \\
\pm 0.01\end{array}$ & $\begin{array}{c}6.99 \\
\pm 0.03\end{array}$ & $\begin{array}{r}13.49 \\
\pm 0.04\end{array}$ \\
\hline S & $(\%$ of $\mathrm{DM})$ & $\begin{array}{c}3.10 \\
\pm 0.02\end{array}$ & $\begin{array}{c}0.37 \\
\pm 0.005\end{array}$ & $\begin{array}{c}0.91 \\
\pm 0.02\end{array}$ \\
\hline $\mathrm{Si}$ & $(\%$ of DM) & $\begin{array}{c}6.84 \\
\pm 0.05\end{array}$ & $\begin{array}{r}17.98 \\
\pm 0.09\end{array}$ & $\begin{array}{c}2.04 \\
\pm 0.16\end{array}$ \\
\hline $\mathrm{Cd}$ & $(\mathrm{mg} / \mathrm{kg} \mathrm{DM})$ & $<2$ & $\begin{array}{c}9.0 \\
\pm 0.1\end{array}$ & $<2$ \\
\hline $\mathrm{Cr}$ & $(\mathrm{mg} / \mathrm{kg} \mathrm{DM})$ & $\begin{array}{l}27.1 \\
\pm 0.7\end{array}$ & $\begin{array}{l}108 \\
\pm 1\end{array}$ & $\begin{array}{r}30.2 \\
\pm 1.2\end{array}$ \\
\hline $\mathrm{Cu}$ & $(\mathrm{mg} / \mathrm{kg} \mathrm{DM})$ & $\begin{array}{l}377 \\
\pm 7\end{array}$ & $\begin{array}{l}722 \\
\pm 3\end{array}$ & $\begin{array}{l}140 \\
\pm 2\end{array}$ \\
\hline $\mathrm{Ni}$ & $(\mathrm{mg} / \mathrm{kg} \mathrm{DM})$ & $\begin{array}{r}19.7 \\
\pm 0.3\end{array}$ & $\begin{array}{r}56.2 \\
\pm 0.7\end{array}$ & $\begin{array}{l}11.7 \\
\pm 0.4\end{array}$ \\
\hline $\mathrm{Pb}$ & $(\mathrm{mg} / \mathrm{kg} \mathrm{DM})$ & $<2$ & $\begin{array}{l}212 \\
\pm 2\end{array}$ & $<2$ \\
\hline $\mathrm{Zn}$ & $(\mathrm{mg} / \mathrm{kg} \mathrm{DM})$ & $\begin{array}{c}1708 \\
\pm 60\end{array}$ & $\begin{array}{c}2548 \\
\pm 49\end{array}$ & $\begin{array}{r}469 \\
\pm 18 \\
\end{array}$ \\
\hline
\end{tabular}

Table 2 Mineral composition of the crystalline phase of the PMA, SSA and MBMA obtained with XRD (\% of DM).

\begin{tabular}{|c|c|c|c|c|c|}
\hline & & & $\begin{array}{c}\text { PMA } \\
(\% \text { of DM) }\end{array}$ & $\begin{array}{c}\text { SSA } \\
(\% \text { of DM) }\end{array}$ & $\begin{array}{c}\text { MBMA } \\
\text { (\% of DM) }\end{array}$ \\
\hline Carbonates & Calcite & $\mathrm{CaCO}_{3}$ & 6.1 & & 0.1 \\
\hline \multirow[t]{2}{*}{ Halides } & Halite & $\mathrm{NaCl}$ & & 0.2 & \\
\hline & Sylvite & $\mathrm{KCl}$ & 5.1 & & 2.7 \\
\hline \multirow[t]{5}{*}{ Oxides } & Hematite & $\mathrm{Fe}_{2} \mathrm{O}_{3}$ & & 6.4 & \\
\hline & Lime & $\mathrm{CaO}$ & & & 5.8 \\
\hline & Magnetite & $\mathrm{Fe}_{3} \mathrm{O}_{4}$ & & 5.6 & 2.3 \\
\hline & Periclase & $\mathrm{MgO}$ & 3.8 & & 1.5 \\
\hline & Portlandite & $\mathrm{Ca}(\mathrm{OH})_{2}$ & 2.1 & & \\
\hline \multirow[t]{4}{*}{ Phosphates } & Apatite & $\mathrm{Ca} 5\left(\mathrm{PO}_{4}\right)_{3}(\mathrm{OH}, \mathrm{Cl}, \mathrm{F})$ & 10.0 & 0.7 & 49.8 \\
\hline & Buchwaldite & $\mathrm{NaCaPO}_{4}$ & & & 12.2 \\
\hline & KNaCa-phosphate* & $\mathrm{KNaCa}_{2}\left(\mathrm{PO}_{4}\right)_{2}$ & 6.0 & & \\
\hline & Whitlockite & $\mathrm{Ca}_{9}(\mathrm{Mg}, \mathrm{Fe})\left(\mathrm{PO}_{4}\right)_{6}\left(\mathrm{PO}_{3} \mathrm{OH}\right)$ & & 13.3 & \\
\hline \multirow[t]{5}{*}{ Silicates } & Alkalifeldspar & $(\mathrm{Na}, \mathrm{K}) \mathrm{AlSi}_{3} \mathrm{O}_{8}$ & & 3.5 & \\
\hline & Cristobalite & $\mathrm{SiO}_{2}$ & & 2.2 & \\
\hline & Plagioclase & $(\mathrm{Na}, \mathrm{Ca})(\mathrm{Si}, \mathrm{Al})_{4} \mathrm{O}_{8}$ & & 2.4 & \\
\hline & Quartz & $\mathrm{SiO}_{2}$ & 6.2 & 24.4 & 1.6 \\
\hline & Tridymite & $\mathrm{SiO}_{2}$ & & 3.6 & \\
\hline \multirow[t]{4}{*}{ Sulfates } & Anhydrite & $\mathrm{CaSO}_{4}$ & & 0.8 & \\
\hline & Aphthitalite & $(\mathrm{K}, \mathrm{Na})_{3} \mathrm{Na}\left(\mathrm{SO}_{4}\right)_{2}$ & 4.4 & & 1.7 \\
\hline & Arcanite & $\mathrm{K}_{2} \mathrm{SO}_{4}$ & 7.9 & & \\
\hline & Polyhalite & $\mathrm{K}_{2} \mathrm{Ca}_{2} \mathrm{Mg}\left(\mathrm{SO}_{4}\right)_{4} .2 \mathrm{H}_{2} \mathrm{O}$ & & 0.8 & \\
\hline Other/amorphous & & & 48.4 & 36.2 & 22.3 \\
\hline
\end{tabular}

* The crystal structure and specific composition of the $\mathrm{KNaCa}$-phosphate mineral is not well known (yet) and its quantification is therefore semi-quantitative. 


\subsection{P extraction}

Fig. 1 gives the solubility curves as function of $\mathrm{pH}$ for different $\mathrm{P}$ compounds (Al-, $\mathrm{Ca}$-, $\mathrm{Fe}$ - and $\mathrm{Mg}$-phosphates) calculated with Visual MINTEQ. From this figure, it is clear that $\mathrm{P}$ can be extracted from the ash in two different ways depending on the $\mathrm{P}$ mineralogy. On the one hand, in an acid solution, $\mathrm{P}$ can be extracted by protonation of $\mathrm{PO}_{4}^{3-}$ in the ash resulting in $\mathrm{HPO}_{4}^{2-}, \mathrm{H}_{2} \mathrm{PO}_{4}^{-}$and finally $\mathrm{H}_{3} \mathrm{PO}_{4}$. This is for instance the case for some of the Ca-, $\mathrm{Mg}$-, $\mathrm{Al}$ - and Fe-phosphates. However, high amounts of $\mathrm{P}$ can only be extracted if the $\mathrm{pH}$ of the extraction liquid is sufficiently low, for instance at $\mathrm{pH}<$ 1 for $\mathrm{AlPO}_{4}$ or at $\mathrm{pH}<4$ for $\mathrm{Ca}_{3}\left(\mathrm{PO}_{4}\right)_{2}$ (see Fig. 1). On the other hand, in an alkaline solution, $\mathrm{P}$ can be extracted by formation of a hydroxide complexion with the phosphate counter ion (e.g., $\left.\mathrm{Al}(\mathrm{OH})_{4}^{-}\right)$. This is for instance the case for some of the Aland Fe-phosphates, which dissolve well at high $\mathrm{pH}$ (see Fig. 1). Most processes for P recovery from incineration ash that are implemented or still under development are based on the principle of $\mathrm{P}$ extraction in an acid solution. Some examples of processes are TetraPhos (dissolving P in SSA and MBMA by phosphoric acid), Phos4Life (dissolving P in SSA by sulfuric acid) and Ash2Phos (dissolving P in SSA by hydrochloric acid or sulfuric acid). On the other hand, P extraction in an alkaline solution has rarely been applied. An example is the Metawater process where $\mathrm{P}$ in SSA is mainly extracted from $\mathrm{AlPO}_{4}$ by sodium hydroxide $[44,45]$. A more detailed description of these processes and other processes can be found in ESPP et al. [45] and Kabbe and Rinck-Pfieffer [44].

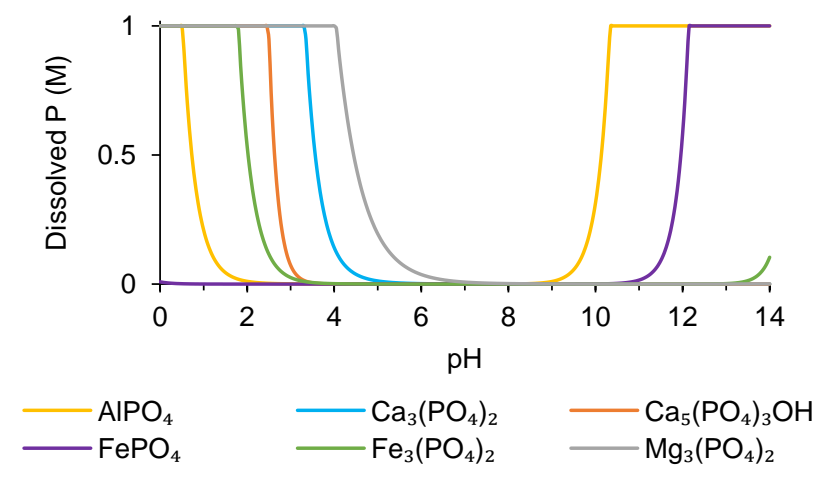

Fig. 1 Solubility curves as function of $\mathrm{pH}$ for different $\mathrm{P}$ compounds calculated with Visual MINTEQ 3.1. AlPO 4 belongs to the group of the Al-phosphates, $\mathrm{Ca}_{3}\left(\mathrm{PO}_{4}\right)_{2}$ and $\mathrm{Ca} 5\left(\mathrm{PO}_{4}\right)_{3} \mathrm{OH}$ belong to the group of the Ca-phosphates, $\mathrm{FePO}_{4}$ and $\mathrm{Fe}_{3}\left(\mathrm{PO}_{4}\right)_{2}$ belong to the group of the Fe-phosphates, and $\mathrm{Mg}_{3}\left(\mathrm{PO}_{4}\right)_{2}$ belongs to the group of the Mg-phosphates.

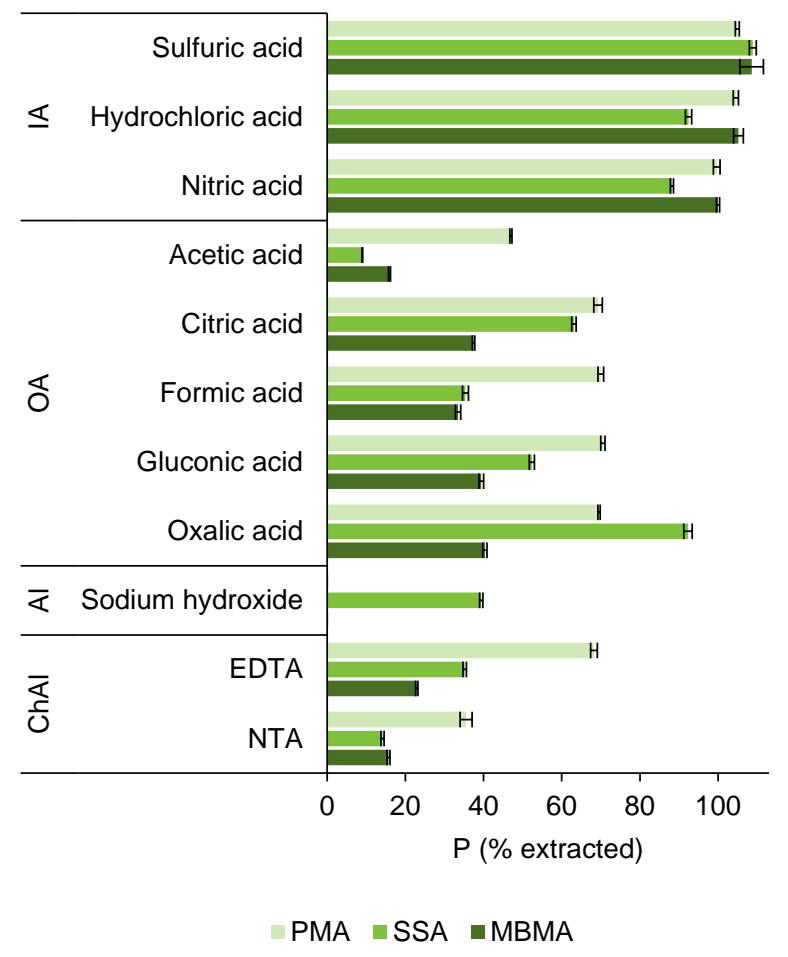

Fig. 2 Efficiency of P extraction from the PMA, SSA and MBMA for all extraction liquids considered (\%). The error bars indicate plus and minus one standard deviation $(n=3$, subsamples from the same sample). Extraction efficiencies of more than $100 \%$ can be attributed to slight interferences in ICP-OES measurements. IA = inorganic acids; $\mathrm{OA}=$ organic acids; $\mathrm{Al}=$ alkaline solution; $\mathrm{ChAl}=$ chelating agents in alkaline solution. 
Table 3 The $\mathrm{pH}$ at the start and at the end of the extraction procedure for all extraction liquids considered (concentration $=0.5 \mathrm{~N}, \mathrm{~L} / \mathrm{S}$ ratio $=50 \mathrm{ml} / \mathrm{g}$ ash, contact time $=2 \mathrm{~h})$.

\begin{tabular}{|c|c|c|c|c|c|}
\hline & & $\begin{array}{c}\text { Start } \\
\text { All ash types }\end{array}$ & $\begin{array}{c}\text { End } \\
\text { PMA }\end{array}$ & $\begin{array}{l}\text { End } \\
\text { SSA }\end{array}$ & $\begin{array}{c}\text { End } \\
\text { MBMA }\end{array}$ \\
\hline \multirow[t]{3}{*}{ Inorganic acids } & Sulfuric acid & 0.5 & 0.9 & 0.7 & 0.9 \\
\hline & Hydrochloric acid & 0.3 & 0.7 & 0.4 & 0.6 \\
\hline & Nitric acid & 0.3 & 0.6 & 0.4 & 0.6 \\
\hline \multirow[t]{5}{*}{ Organic acids } & Acetic acid & 2.4 & 4.3 & 3.1 & 3.9 \\
\hline & Citric acid & 1.8 & 3.4 & 2.4 & 3.0 \\
\hline & Formic acid & 1.7 & 3.1 & 2.1 & 2.7 \\
\hline & Gluconic acid & 1.7 & 3.3 & 2.3 & 2.8 \\
\hline & Oxalic acid & 0.9 & 1.3 & 1.0 & 1.1 \\
\hline Alkaline solution & Sodium hydroxide & 13.0 & 13.3 & 13.2 & 13.2 \\
\hline \multirow[t]{2}{*}{ Chelating agents in alkaline solution } & EDTA & 9.8 & 12.2 & 9.9 & 12.1 \\
\hline & NTA & 10.0 & 11.9 & 9.9 & 12.1 \\
\hline
\end{tabular}

Fig. 2 gives the efficiency of P extraction from the PMA, SSA and MBMA for all extraction liquids considered (The P concentration in the three ash types differs. For the sake of completeness, the P extraction mass balance data can be consulted in the supplementary material, Fig. S1). The $\mathrm{pH}$ at the start and at the end of the extraction procedure for all extraction liquids considered can be consulted in Table 3. Fig. 2 indicates that the P extraction efficiency was in general higher for the inorganic acids (sulfuric acid, hydrochloric acid and nitric acid) than for the other extraction liquids. There are two explanations for these higher P extraction efficiencies. First, this can be explained by the fact that the inorganic acids considered were all strong acids, whereas the organic acids considered (acetic acid, citric acid, formic acid, gluconic acid and oxalic acid) were all weak acids. In general, strong acids release more protons than weak acids and hence result in more protonation of $\mathrm{PO}_{4}^{3-}$ and accordingly in a higher $\mathrm{P}$ extraction efficiency. Second, XRD analysis showed that at least part of the $\mathrm{P}$ in the three ash types was bound as Ca-phosphates (e.g. apatite and whitlockite, see Table 3). These Ca-phosphates are poorly soluble in an alkaline environment (see Fig. 1), explaining the lower P extraction efficiencies obtained with the alkaline extraction solutions (sodium hydroxide, EDTA and NTA) compared to the inorganic acids [28, 46]. It should, however, be noted that the $\mathrm{P}$ extraction efficiency in an alkaline environment increased considerably in the presence of chelating agents, except for the SSA (see Fig. 2). This might be due to the fact that chelating agents such as EDTA and NTA can form highly soluble complexes with the phosphate counter ions such as $\mathrm{Al}, \mathrm{Ca}, \mathrm{Fe}$ and $\mathrm{Mg}$ [47-49]. Hence, strong complex formation with for instance $\mathrm{Ca}$ will shift the Ca-phosphate dissolution reaction to the right, even if Ca-phosphates as such are poorly soluble in an alkaline environment. The latter is discussed in more detail in the last paragraph of section 3.2.3.

\subsubsection{P extraction by inorganic acids}

The P extraction efficiency was for all inorganic acids and for all ash types $>88 \%$ (see Fig. 2). This is in line with previously reported results, amongst others, by Darwish et al. [29], Fang et al. [22], Kootstra et al. [12] and Leng et al. [16]. However, as discussed in the introduction section, a one-on-one comparison with literature data is almost impossible due to differences in extraction settings and ash properties. These overall high $\mathrm{P}$ extraction efficiencies indicate that the $\mathrm{P}$ extraction efficiency for the inorganic acids was not or only slightly affected by the specific P mineralogy of the different ash types. This might be attributed to the low $\mathrm{pH}$ at the end of the extraction procedure, which was $<1$ for all three inorganic acids and for all three ash types (see Table 3). According to Fig. 1, almost all phosphate compounds indeed show high solubility at pH $<1$.

All extraction liquids other than the inorganic acids showed differences in P extraction efficiency between the three ash types and between the different extraction liquids (see Fig. 2). These differences are most likely due to differences in P mineralogy, elemental composition of the ash, and/or chemical characteristics of the extraction liquids. However, the fact that the ash types contained a considerable fraction of amorphous $\mathrm{P}$ from which the mineralogy could not be determined, especially the PMA and SSA (52\% and 59\% of total P, respectively), made it difficult to directly link the P mineralogy to the $\mathrm{P}$ extraction efficiency. Yet, below, an attempt is made to explain the differences in $\mathrm{P}$ extraction efficiency based on the $\mathrm{P}$ mineralogy, elemental composition of the ash and known chemical characteristics of the extraction liquids.

\subsubsection{P extraction by organic acids}

Of all organic acids considered, oxalic acid is the strongest acid $\left(\mathrm{pK}_{\mathrm{a} 1}=1.25\right)$, followed by citric acid $\left(\mathrm{pK}_{\mathrm{a} 1}=3.13\right)$, gluconic acid $\left(\mathrm{pK}_{\mathrm{a}}=3.60\right)$, formic acid $\left(\mathrm{pK}_{\mathrm{a}}=3.75\right)$ and acetic acid $\left(\mathrm{pK}_{\mathrm{a}}=4.76\right)$. The lower the $\mathrm{pK}_{\mathrm{a}}$ value, the higher the dissociation constant $\left(\mathrm{K}_{\mathrm{a}}\right)$ and hence the more the acid will dissociate in aqueous solutions, which is reflected in lower $\mathrm{pH}$ values. As discussed when comparing the strong and weak acids, lower $\mathrm{pH}$ values favor $\mathrm{P}$ extraction from the ash because of more protonation of $\mathrm{PO}_{4}^{3-}[12,21,30]$. Hence, it can be concluded that the $\mathrm{pK}_{\mathrm{a}}$ values of the organic acids are inversely proportional to the $\mathrm{P}$ extraction efficiency for SSA. Indeed, of all organic acids considered, oxalic acid showed the highest P extraction efficiency for SSA (92\%), followed by citric acid (63\%), gluconic acid (52\%), formic acid (35\%) and acetic acid (9\%). Research by Atienza-Martinez et al. [7], Fang et al. [22] and Liang et al. [9] previously revealed that high P extraction efficiencies can indeed be obtained when extracting P from SSA by oxalic acid. However, differences in extraction settings impede the one-on-one comparison of literature data and the data in this research. Furthermore, for citric acid, a similar P extraction efficiency from SSA was previously obtained by Fang et al. [22], again taking into account other 
extraction settings. However, to the authors knowledge, P extraction from SSA by one of the other organic acids considered in this research (acetic acid, formic acid and gluconic acid) have not previously been under investigation.

Furthermore, Fig. 2 shows that the citric acid, formic acid and gluconic acid P extraction efficiency for PMA varied between $69 \%$ and $71 \%$, whereas they varied between $33 \%$ and 39\% for MBMA. Below, it is demonstrated how these P extraction efficiencies may be linked to the P mineralogy. First, based on the work by Kratz et al. [34] it is hypothesized that buchwaldite and $\mathrm{KNaCa}$-phosphate show a higher solubility than apatite, and that amorphous $\mathrm{P}$ shows a higher solubility than crystalline P. Second, the solubility curve of hydroxyapatite ${ }^{1}\left(\mathrm{Ca}_{5}\left(\mathrm{PO}_{4}\right)_{3} \mathrm{OH}\right)($ see Fig. 1) indicates that this $\mathrm{P}$ mineral is highly soluble until a $\mathrm{pH}$ of about 2.5 . The $\mathrm{pH}$ at the end of the extraction procedure for citric acid, formic acid and gluconic acid varied between 3.1 and 3.4 for PMA and between 2.7 and 3.0 for MBMA (see Table 3). Therefore, it is hypothesized that the $30 \%$ and $67 \%$ of total P bound as apatite in the PMA and MBMA did as good as not dissolve when extracted with citric acid, formic acid and gluconic acid. Indeed, the fraction of $\mathrm{P}$ bound as apatite corresponds rather well with the fraction of $\mathrm{P}$ not dissolving in these three extraction liquids $(29-31 \%$ for PMA and $61-67 \%$ for MBMA, respectively). In addition, it was found that the acetic acid P extraction efficiency for PMA and MBMA was much lower than for all other organic acids (see Fig. 2), which might be related to the low $\mathrm{pK}_{\mathrm{a}}$ value of acetic acid.

It should be noted that the oxalic acid P extraction efficiency for SSA was within the same range as that of the inorganic acids (92\%), whereas it was much lower for PMA and MBMA (70\% and 40\%, respectively). The pH at the end of the extraction procedure for oxalic acid varied between 1.0 and 1.3 for all three ash types. According to Fig. 1 and the discussion in the previous paragraph, it was expected that apatite and all other phosphates would totally dissolve at these $\mathrm{pH}$ values, resulting in $\mathrm{P}$ extraction efficiencies of about $100 \%$ for all three ash types. However, this was not the case and it is hypothesized here that this might be linked to the Ca concentration in the ash types. From Fig. 2 and Table 1 it can be concluded that the $\mathrm{P}$ extraction efficiency for oxalic acid is inversely proportional to the $\mathrm{Ca}$ concentration in the ash types (6.64\% of DM for SSA, $21.12 \%$ of DM for PMA and $33.63 \%$ of DM for MBMA). During oxalic acid extraction, the Ca initially extracted from the ash binds with oxalate and forms poorly soluble Ca-oxalate [9, 12, 22]. Ca-oxalate precipitate formation might obstruct the acid penetration towards the core of the not yet dissolved ash particles. This Ca-oxalate precipitate formation will probably decrease the dissolution of $\mathrm{P}$ from the ash and most likely at some point $\mathrm{P}$ extraction will even stop due to the formation of a high amount of Ca-oxalate. Hence, it is expected that ash types with a higher Ca concentration will most likely reach the point of Ca-oxalate blocking already at a lower $\mathrm{P}$ extraction efficiency. It is worth noting that during sulfuric acid extraction a precipitate is also formed, i.e., gypsum [9, 21, 22, 25]. However, gypsum has a higher molar solubility than $\mathrm{Ca}$-oxalate over the full $\mathrm{pH}$ range (for instance, at $\mathrm{pH} 1, \mathrm{~s}=4.1 \times 10^{-2} \mathrm{M}$ for gypsum and $4.9 \times$ $10^{-3} \mathrm{M}$ for Ca-oxalate, respectively (data from Visual MINTEQ)). Therefore, less gypsum precipitate formation is expected compared to Ca-oxalate precipitate formation and hence less acid penetration obstruction is expected. For all other extraction liquids than oxalic acid, sulfuric acid and sodium hydroxide, it was found that the amount of Ca extracted was proportional to the amount of P extracted (data shown in supplementary material Fig. S2).

\subsubsection{P extraction by alkaline extraction liquid and chelating agents}

The P extraction efficiency with sodium hydroxide was 0\% for PMA and MBMA, whereas it was 39\% for SSA (see Fig. 2). The $\mathrm{pH}$ at the end of the extraction procedure with sodium hydroxide varied between 13.2 and 13.3 . In Fig. 1 it can be seen that in this $\mathrm{pH}$ range some of the $\mathrm{Al}$ - and $\mathrm{Fe}$-phosphates dissolve well, whereas $\mathrm{Ca}$ - and $\mathrm{Mg}$-phosphates are in general poorly soluble $[28,46]$. Hence, this indicates that hardly any Al- and or Fe-phosphates were present in the unknown amorphous phase of the PMA and MBMA. This might be related to the low Al and Fe content in PMA and MBMA compared to SSA. Furthermore, it can be concluded that at least part of the unknown amorphous P in the SSA consisted of Al- and/or Fe-phosphates since no Al- and/or Fe-phosphates were detected in the crystalline phase by the XRD analysis. Indeed, the presence of Al- and/or Fe-phosphates in SSA has been previously confirmed in studies by Lee and Kim [46], Liang et al. [9], Peplinski et al. [50] and Petzet et al. [28]. The presence of Al- and/or Fe-phosphates in SSA can be linked to the addition of soluble Al- and/or Fe-compounds such as alum or iron(III) chloride to the wastewater to precipitate the dissolved P that is subsequently removed with the SS.

The P extraction efficiency for PMA and MBMA in alkaline environment increased considerably in the presence of chelating agents. Fig. 2 clearly shows that EDTA extraction resulted in higher P extraction efficiencies than NTA extraction. This might be due to the fact that EDTA can form more stable complexes than NTA with most metals because of higher formation constants $\left(\mathrm{K}_{\mathrm{f}}\right)$. For instance, the Ca-EDTA complex $\left(\log \mathrm{K}_{\mathrm{f}}=10.69\right)$ is more stable than the Ca-NTA complex $\left(\log \mathrm{K}_{\mathrm{f}}=6.41\right)$. The more stable complexes ensured that the $\mathrm{Ca}$ or other metals bound to the $\mathrm{P}$ in the ashes more easily dissolved in the extraction liquid, simultaneously dissolving the $\mathrm{P}$ and thus resulting in higher $\mathrm{P}$ extraction efficiencies. Contrarily, the P extraction efficiency for SSA in alkaline environment decreased in the presence of chelating agents. This can probably be explained by the combination of the following two facts, both linked to the $\mathrm{pH}$ at the end of the extraction procedure. First, in Table 3 it can be seen that the $\mathrm{pH}$ at the end of the sodium hydroxide extraction procedure for SSA was 13.2, whereas this was 9.9 for EDTA and NTA extraction. Both $\mathrm{AlPO}_{4}$ and $\mathrm{FePO}_{4}$ show relatively low solubilities at $\mathrm{pH} 9.9$ $(<25 \%)$, whereas they are completely soluble at $\mathrm{pH} 13.2$ (see Fig. 1). Hence, it is likely that the amorphous Al- and/or Fephosphates that dissolved from the SSA when extracted with sodium hydroxide no longer dissolved or at least to a much

\footnotetext{
${ }^{1}$ Visual MINTEQ databases do not contain data on the chlorapatite $\left(\mathrm{Ca}_{5}\left(\mathrm{PO}_{4}\right)_{3} \mathrm{Cl}\right)$ and fluorapatite $\left(\mathrm{Ca}_{5}\left(\mathrm{PO}_{4}\right)_{3} \mathrm{~F}\right)$ solubility. However, in the literature, it was found that for the ash types studied, apatite mainly occurs in the form of hydroxyapatite and only to a lesser extent in the form of chlorapatite and fluorapatite [19, 20, 26, 34]. Therefore, the conclusions in this paragraph are only based on the hydroxyapatite solubility.
} 
lesser degree for EDTA and NTA extraction. Second, as for the PMA and MBMA, it was expected that phosphates in the SSA can dissolve through complex formation of chelating agents with the phosphate counter ion. However, the stability of EDTA and NTA complexes deteriorates with decreasing pH $[49,51,52]$. Hence, the complexes for the PMA and MBMA extraction were more stable than for the SSA extraction because of the higher $\mathrm{pH}$ at the end of the EDTA and NTA extraction procedure (11.9 - 12.2 for PMA and MBMA, and 9.9 for SSA, respectively). Indeed, the fraction of EDTA and NTA present in its fully deprotonated form, at which the metal complexes are most stable, depends on the $\mathrm{pH}$ of the solution [49, 51, 52]. For instance, at pH 10 only $37 \%$ of the EDTA is present in its fully deprotonated form, whereas this is almost $100 \%$ at pH 12 [51]. Hence, the $\mathrm{pH}$-dependent conditional formation constant $\left(\mathrm{K}_{\mathrm{f}}^{\prime}\right)$, considering the limited availability of fully deprotonated chelates, is lower at $\mathrm{pH} 10$ than at $\mathrm{pH} 12$ which explains the lower complex stability at lower $\mathrm{pH}$. In short, the $\mathrm{P}$ extraction efficiency for SSA in alkaline environment decreased in the presence of chelating agents due to the lower $\mathrm{pH}$ at which both less Al- and Fe-phosphates dissolve and due to the presence of only little amounts of fully deprotonated EDTA and NTA for complexation of the phosphate counter ions.

\subsection{Heavy metal extraction}

Fig. 3 and Fig. 4 give the efficiencies of $\mathrm{Cd}, \mathrm{Cr}, \mathrm{Cu}, \mathrm{Ni}, \mathrm{Pb}$ and $\mathrm{Zn}$ extraction from the PMA, SSA and MBMA for all extraction liquids considered (The heavy metal concentration in the three ash types differs. For the sake of completeness, heavy metal extraction mass balance data can be consulted in the supplementary material, Fig. S3 and Fig. S4). The concentration of $\mathrm{Cd}$ and $\mathrm{Pb}$ in the PMA and MBMA was below the detection limit value of the ICP-OES measurements (2 $\mathrm{mg} / \mathrm{kg} \mathrm{DM}$, see Table 1) and therefore the $\mathrm{Cd}$ and $\mathrm{Pb}$ extraction efficiencies in Fig. 4 are only given for SSA.

Fig. 3 shows that the $\mathrm{Cr}, \mathrm{Cu}, \mathrm{Ni}$ and $\mathrm{Zn}$ extraction efficiencies were in general higher for the PMA and MBMA than for the SSA. However, Table 1 shows that the heavy metal concentrations in the initial ash were in general highest in the SSA, followed by the PMA and MBMA. The mass balances in the supplementary material (Fig. S3) show that the extracted amount of $\mathrm{Cu}, \mathrm{Ni}$ and $\mathrm{Zn}$ were in general highest for PMA, followed by SSA and MBMA, whereas the extracted amount of $\mathrm{Cr}$ was in general highest for MBMA, followed by PMA and SSA. This shows that there is no direct relationship between the concentration of the heavy metals in the three ash types and the amount of heavy metals that is extracted from these three ash types. This might be explained based on the differences in speciation of the heavy metals. Unfortunately, the mineralogy of the heavy metals could not be detected by XRD due to their low concentrations in the three ash types. However, based on the results obtained with the extraction experiments, it could be assumed that most of the heavy metals in the SSA were bound in poorly soluble silicates, aluminates or oxides due to the high contents of Si and Al in the SSA [53, 54]. In the PMA and MBMA, it is more likely that the heavy metals were bound in more soluble compounds such as chlorides or sulfates.

Overall, the alkaline extraction liquids (sodium hydroxide, EDTA and NTA) had the lowest heavy metal extraction efficiencies for all three ash types considered (see Fig. 3 and Fig. 4). This could mainly be explained by the high pH at the end of the extraction procedure (ranging between 9.9 and 13.3), since most heavy metal compounds show low solubility at high $\mathrm{pH}[55,56]$. However, the $\mathrm{P}$ extraction efficiency for these alkaline extraction liquids was also relatively low $(<39 \%)$, except for EDTA extraction of PMA (68\%). Nonetheless, it was expected that extraction with complexing agents would result in relatively high heavy metal extraction efficiencies due to formation of highly soluble heavy metal complexes [47, 48]. However, the results in Fig. 3 and Fig. 4 showed a tendency opposite to the expectations. On the one hand, the limited heavy metal complexation might be attributed to competition for the complexion with major ash elements such as $\mathrm{Ca}$, $\mathrm{Al}$ and $\mathrm{Fe}[47,48]$. On the other hand, it might be attributed to the fact that the formation of poorly soluble heavy metal oxides or hydroxides competes with the chelating agents at high $\mathrm{pH}[52,57]$. For instance, $\mathrm{Zn}(\mathrm{OH})_{2}$ is poorly soluble $\left(\mathrm{K}_{\mathrm{sp}}=7.71 \mathrm{x}\right.$ $10^{-17}$ ) and hence at high $\mathrm{pH}$ a substantial part of $\mathrm{Zn}$ may precipitate as hydroxide. As a result, less $\mathrm{Zn}$ is available for participating in the complex formation equilibrium and accordingly the formation constant (e.g., $\log \mathrm{K}_{\mathrm{f}}=16.50$ for $\mathrm{Zn}$ EDTA) must be corrected with a factor that reflects the availability of the $\mathrm{Zn}$ ions. In addition, the formation constant has to be corrected for the availability of fully deprotonated chelates at a specific $\mathrm{pH}$ (see discussion in section 3.2.3). Applying these two correction factors gives the conditional formation constant $\left(\mathrm{K}_{\mathrm{f}}\right)$ which is lower than the original formation constant and hence less stable complexes are formed [52].

In general, the highest heavy metal extraction efficiencies were obtained with the inorganic acids (sulfuric acid, hydrochloric acid and nitric acid) (see Fig. 3 and Fig. 4). As discussed in section 3.2.1, these extraction liquids also showed the highest $\mathrm{P}$ extraction efficiencies, indicating that a high $\mathrm{P}$ extraction efficiency coincides inevitably with high heavy metal co-extraction. Nevertheless, EDTA extraction of PMA resulted in a relatively high P extraction efficiency of $68 \%$, combined with relatively low heavy metal co-extraction $(12 \% \mathrm{Cr}, 22 \% \mathrm{Cu}, 13 \% \mathrm{Ni}$ and $17 \% \mathrm{Zn}$ extracted). Obviously, in this case, it must be considered whether the $32 \% \mathrm{P}$ remaining in the PMA solid extraction residue outweighs the possibly lower downstream processing costs for heavy metal removal. 


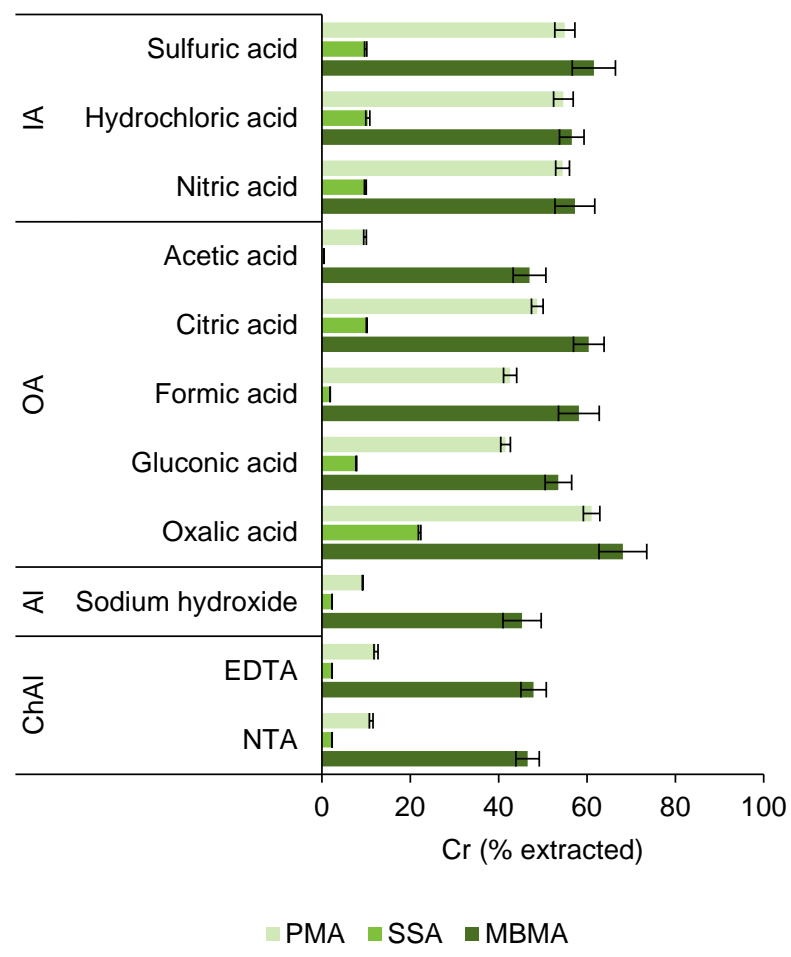

(a)

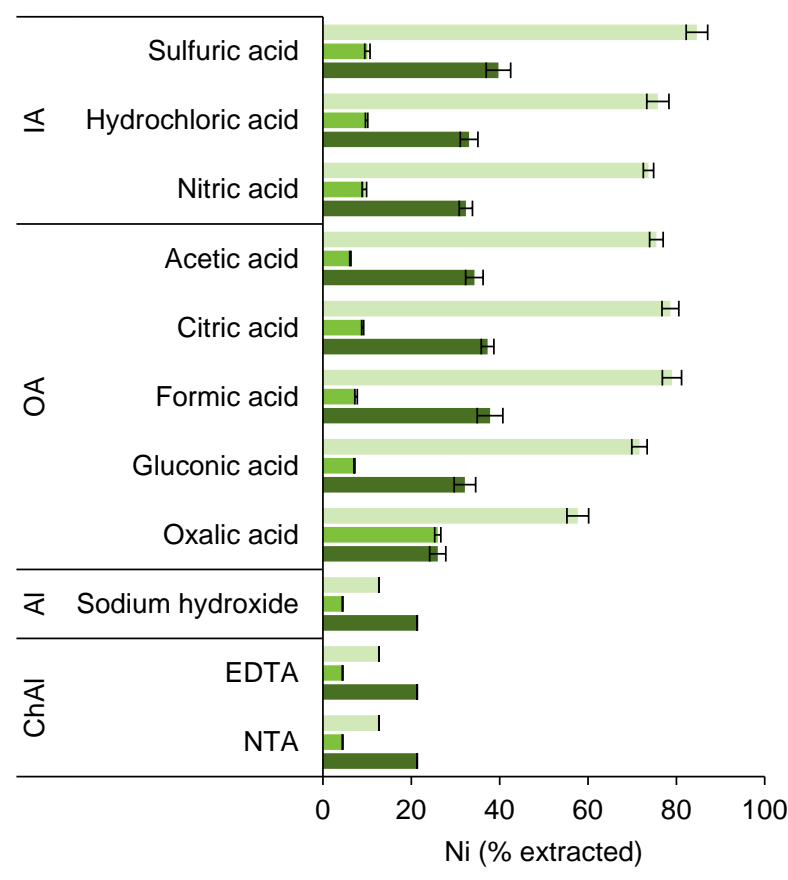

$\square$ PMA $\square$ SSA $\square$ MBMA

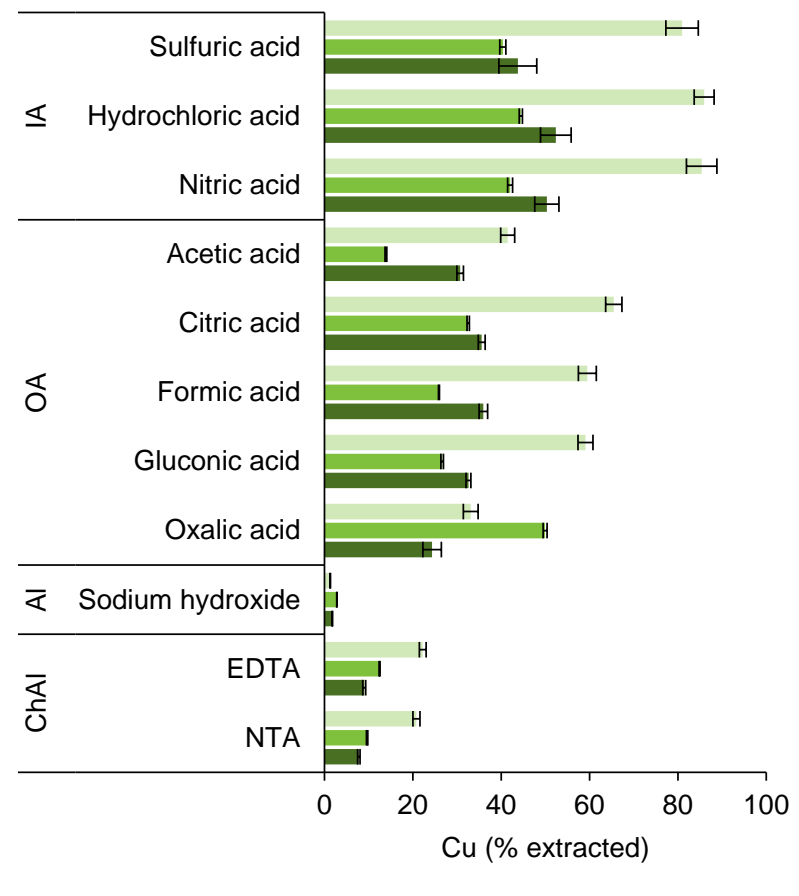

$\square \mathrm{PMA} \backsim \mathrm{SSA} \backsim \mathrm{MBMA}$

(b)

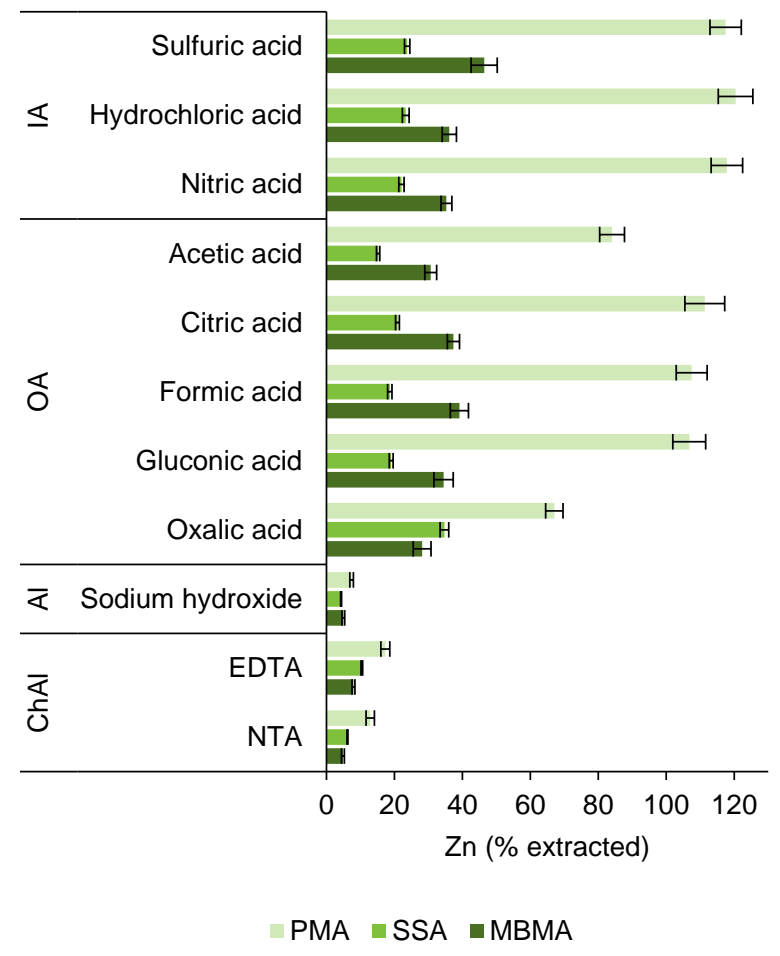

(d)

Fig. 3 Efficiency of $\mathrm{Cr}, \mathrm{Cu}, \mathrm{Ni}$ and $\mathrm{Zn}$ extraction from the PMA, SSA and MBMA for all extraction liquids considered (\%). The error bars indicate plus and minus one standard deviation $(n=3$, subsamples from the same sample). Extraction efficiencies of more than $100 \%$ can be attributed to slight interferences in ICP-OES measurements. IA = inorganic acids; $\mathrm{OA}=$ organic acids; $\mathrm{Al}=$ alkaline solution; $\mathrm{ChAl}$ = chelating agents in alkaline solution. (a) Cr extraction efficiency (\%); (b) Cu extraction efficiency (\%); (c) Ni extraction efficiency (\%); (d) Zn extraction efficiency (\%). 


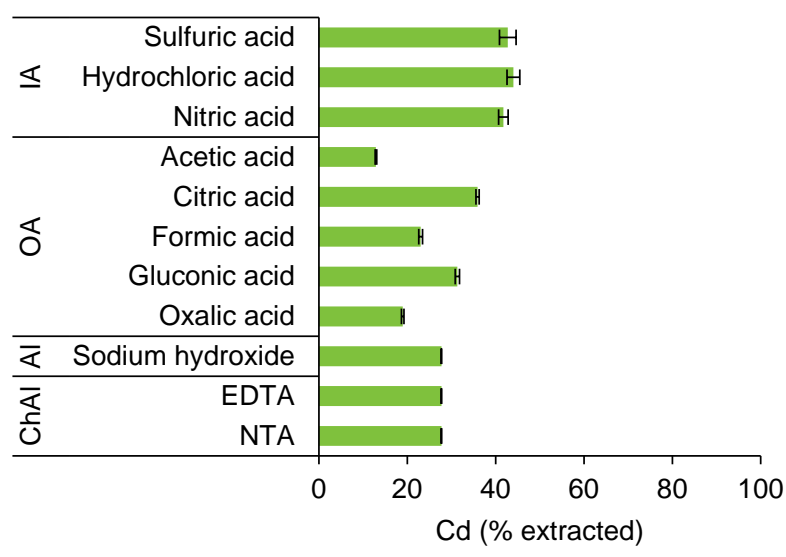

(a)

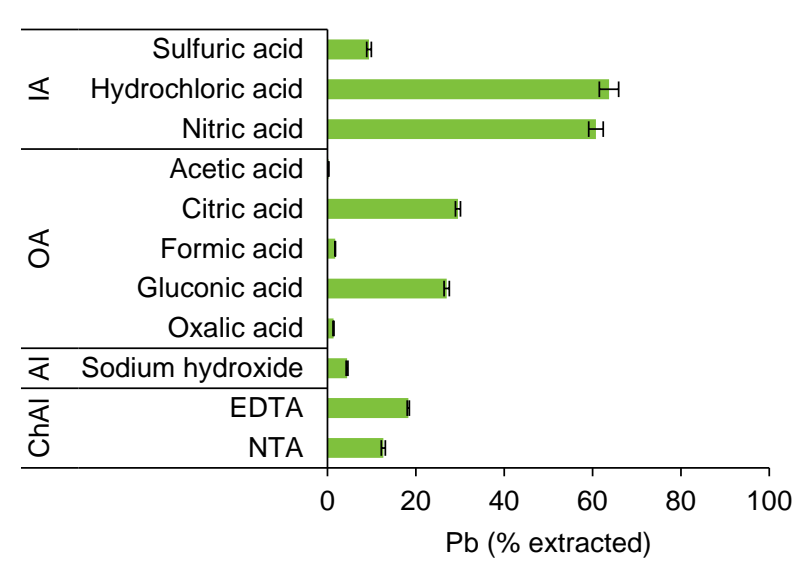

(b)

Fig. 4 Efficiency of $\mathrm{Cd}$ and $\mathrm{Pb}$ extraction from the SSA for all extraction liquids considered (\%). The error bars indicate plus and minus one standard deviation $(\mathrm{n}=3$, subsamples from the same sample). $\mathrm{IA}=$ inorganic acids; $\mathrm{OA}=$ organic acids; $\mathrm{Al}=$ alkaline solution; $\mathrm{ChAl}$ $=$ chelating agents in alkaline solution. (a) Cd extraction efficiency (\%); (b) $\mathrm{Pb}$ extraction efficiency (\%).

\subsection{Selection of optimal extraction liquid}

The discussion in section 3.2 and 3.3 clearly indicates that the selection of the most suited extraction liquid for a specific ash type is affected by the ash mineralogy, elemental composition of the ash, and/or chemical characteristics of the extraction liquids. However, valorization on industrial scale might be facilitated when the same extraction liquid is used to treat several types of ash in the same $\mathrm{P}$ extraction installation. In this case, it is best to select one of the inorganic acids, since all inorganic acids showed good $\mathrm{P}$ extraction efficiencies regardless the difference in $\mathrm{P}$ mineralogy $($ at $\mathrm{pH}<1)$. However, inorganic acid extraction resulted in relatively high heavy metal co-extraction implying further purification of the extract. From an economic point of view, it is in this case most interesting to use sulfuric acid because of the lower extraction liquid costs compared to the other inorganic acids considered (around $0.010 € / \mathrm{mol} \mathrm{H}^{+}$for sulfuric acid, $0.023 € / \mathrm{mol} \mathrm{H}^{+}$for hydrochloric acid and $0.030 € / \mathrm{mol} \mathrm{H}^{+}$for nitric acid) [58]. Furthermore, sulfuric acid extraction is similar to the method applied most for $\mathrm{P}$ extraction from phosphate rock $[5,7]$. Nonetheless, a suitable application for the gypsum and the solid extraction residue has to be found [8].

However, if only one specific ash type is treated in a P extraction installation, EDTA extraction could be an interesting option for the PMA and oxalic acid extraction for the SSA. On the one hand, EDTA extraction of PMA is interesting because of the relatively high $\mathrm{P}$ extraction efficiency (68\%) combined with relatively low heavy metal co-extraction $(12-22 \%)$, possibly decreasing downstream processing costs. Yet, further research should indicate if in this case the economic loss, due to the $32 \%$ of $\mathrm{P}$ that in not extracted from the ash, outweighs these lower downstream processing costs. On the other hand, oxalic acid extraction of SSA is interesting since the P extraction efficiency (92\%) was within the same range as that of the inorganic acids. Furthermore, the use of oxalic acid is interesting because of the fact that the production of organic acids is overall more sustainable than the production of inorganic acids [12].

\section{Conclusions}

PMA, SSA and MBMA are promising alternatives for $\mathrm{P}$ recovery because they are renewable sources with a $\mathrm{P}$ content comparable to that of (low grade) phosphate rock. XRD analysis showed that PMA, SSA and MBMA had a distinct P mineralogy. The efficiency of $\mathrm{P}$ extraction with inorganic acids was very similar for the different ash types, indicating that it was not or only slightly affected by the specific P mineralogy. This can be explained by the fact that the applied concentration of $0.5 \mathrm{~N}$, which was equal for all considered inorganic acids, resulted in $\mathrm{pH}$ values $<1$ at which almost all $\mathrm{P}$ minerals in the ash show high solubility. Contrarily, for the organic acids, alkaline extraction liquid and chelating agents considered, the P extraction efficiency was highly affected by the specific P mineralogy. For these extraction liquids, the extraction of P from PMA, SSA and MBMA in the considered systems showed to be complex, since the ash composition, ash mineralogy and chemical characteristics of the extraction liquids indirectly influence (1) the $\mathrm{pH}$ of the solution which on its turn affects the solubility of the P minerals and (2) the type and the concentration of ions in the solution that can interact.

Heavy metal extraction efficiencies were in general higher for PMA and MBMA than for SSA. Alkaline extraction liquids showed in general low heavy metal extraction efficiencies, in contrast to the inorganic acids, indicating that a high $\mathrm{P}$ extraction efficiency coincides inevitably with high heavy metal co-extraction.

From an economic point of view, it is most interesting to extract $\mathrm{P}$ with sulfuric acid since all three ash types could be treated in the same installation, regardless the difference in $\mathrm{P}$ mineralogy. However, further downstream processing to separate the co-extracted heavy metals from the $\mathrm{P}$ in the extract remains necessary in this case. Oxalic acid could be a more sustainable option than sulfuric acid, but only showed a good P extraction efficiency for SSA. EDTA extraction could be an alternative for $\mathrm{P}$ extraction from PMA, since it showed a relatively high $\mathrm{P}$ extraction efficiency combined with relatively 
low heavy metal co-extraction. The optimal extraction procedure for industrial scale applications, however, will also depend on economic considerations such as the cost of the extraction liquids and the tradeoff between $\mathrm{P}$ extraction efficiency (increasing the revenue) and heavy metal co-extraction (increasing the downstream processing cost).

\section{Acknowledgements}

This study was financially supported by BMC Moerdijk BV (Industrial park M349, Middenweg 36a, 4782 PM Moerdijk, The Netherlands) and Fonds Wetenschappelijk Onderzoek Vlaanderen (FWO) (Lorien Luyckx is a SB PhD fellow at FWO, project number $1 \mathrm{~S} 08418 \mathrm{~N}-1 \mathrm{~S} 08420 \mathrm{~N})$. Furthermore, we want to thank BMC Moerdijk, Aquafin and Indaver for supplying the PMA, SSA and MBM samples. In addition, we want to thank Antoinette Deschuytere for carefully revising the manuscript.

\section{Declarations}

Funding: This study was financially supported by BMC Moerdijk BV (Industrial park M349, Middenweg 36a, 4782 PM Moerdijk, The Netherlands) and Fonds Wetenschappelijk Onderzoek Vlaanderen (FWO) (project number 1S08418N $1 \mathrm{~S} 08420 \mathrm{~N})$.

Competing interests: The authors declare that they have no known competing financial interests or personal relationships that could have appeared to influence the work reported in this paper.

Availability of data and material: Research data is stored and documented in a safe, secure and sustainable way and can be retrieved or accessed when needed.

Code availability: Not applicable. 


\section{References}

1. U.S. Geological Survey (USGS). (2020). Phosphate rock. In Mineral commodity summaries 2020 (pp. 122-123). https://doi.org/10.3133/mcs2020

2. Desmidt, E., Ghyselbrecht, K., Zhang, Y., Pinoy, L., Van der Bruggen, B., Verstraete, W., ... Meesschaert, B. (2015). Global phosphorus scarcity and full-scale P-recovery techniques: A review. Critical Reviews in Environmental Science and Technology, 45(4), 336-384. https://doi.org/10.1080/10643389.2013.866531

3. Mayer, B. K., Baker, L. A., Boyer, T. H., Drechsel, P., Gifford, M., Hanjra, M. A., ... Rittmann, B. E. (2016). Total value of phosphorus recovery. Environmental Science and Technology, 50(13), 6606-6620. https://doi.org/10.1021/acs.est.6b01239

4. Cordell, D., \& White, S. (2013). Sustainable phosphorus measures: Strategies and technologies for achieving phosphorus security. Agronomy, 3(1), 86-116. https://doi.org/10.3390/agronomy3010086

5. Takhim, M., Sonveaux, M., \& de Ruiter, R. (2019). The Ecophos process: Highest quality market products out of low-grade phosphate rock and sewage sludge ash. In H. Ohtake \& S. Tsuneda (Eds.), Phosphorus recovery and recycling (pp. 209-219). https://doi.org/10.1007/978-981-10-8031-9_14

6. Nättorp, A., Kabbe, C., Matsubae, K., \& Ohtake, H. (2019). Development of phosphorus recycling in Europe and Japan. In H. Ohtake \& S. Tsuneda (Eds.), Phosphorus recovery and recycling (pp. 3-27). https://doi.org/10.1007/978-981-10-8031-9_1

7. Atienza-Martínez, M., Gea, G., Arauzo, J., Kersten, S. R. A., \& Kootstra, A. M. J. (2014). Phosphorus recovery from sewage sludge char ash. Biomass and Bioenergy, 65, 42-50. https://doi.org/10.1016/j.biombioe.2014.03.058

8. Donatello, S., \& Cheeseman, C. R. (2013). Recycling and recovery routes for incinerated sewage sludge ash (ISSA): A review. Waste Management, 33(11), 2328-2340. https://doi.org/10.1016/j.wasman.2013.05.024

9. Liang, S., Chen, H., Zeng, X., Li, Z., Yu, W., Xiao, K., ... Yang, J. (2019). A comparison between sulfuric acid and oxalic acid leaching with subsequent purification and precipitation for phosphorus recovery from sewage sludge incineration ash. Water Research, 159, 242-251. https://doi.org/10.1016/j.watres.2019.05.022

10. Adam, C., Peplinski, B., Michaelis, M., Kley, G., \& Simon, F.-G. (2009). Thermochemical treatment of sewage sludge ashes for phosphorus recovery. Waste Management, 29(3), $1122-1128$. https://doi.org/10.1016/j.wasman.2008.09.011

11. Van de Velden, M., Dewil, R., Baeyens, J., Josson, L., \& Lanssens, P. (2008). The distribution of heavy metals during fluidized bed combustion of sludge (FBSC). Journal of Hazardous Materials, 151(1), 96-102. https://doi.org/10.1016/j.jhazmat.2007.05.056

12. Kootstra, A. M. J., Brilman, D. W. F., \& Kersten, S. R. A. (2019). Dissolution of phosphate from pig manure ash using organic and mineral acids. Waste Management, 88, 141-146. https://doi.org/10.1016/j.wasman.2019.03.038

13. Langeveld, K. (2019). Phosphorus recovery into fertilizers and industrial products by ICL in Europe. In H. Ohtake \& S. Tsuneda (Eds.), Phosphorus recovery and recycling (pp. 235-252). https://doi.org/10.1007/978-981-10-8031$9 \_16$

14. Nusselder, S., de Graaff, L. G., Odegard, I. Y. R., Vandecasteele, C., \& Croezen, H. J. (2020). Life cycle assessment and nutrient balance for five different treatment methods for poultry litter. Journal of Cleaner Production, 267, 121862. https://doi.org/10.1016/j.jclepro.2020.121862

15. Komiyama, T., Kobayashi, A., \& Yahagi, M. (2013). The chemical characteristics of ashes from cattle, swine and poultry manure. Journal of Material Cycles and Waste Management, 15, 106-110. https://doi.org/10.1007/s10163012-0089-2

16. Leng, L., Bogush, A. A., Roy, A., \& Stegemann, J. A. (2019). Characterisation of ashes from waste biomass power plants and phosphorus recovery. Science of the Total Environment, 690, 573-583. https://doi.org/10.1016/j.scitotenv.2019.06.312

17. Billen, P., Costa, J., Van der Aa, L., Van Caneghem, J., \& Vandecasteele, C. (2015). Electricity from poultry manure: A cleaner alternative to direct land application. Journal of Cleaner Production, 96, 467-475. https://doi.org/10.1016/j.jclepro.2014.04.016

18. Luyckx, L., de Leeuw, G. H. J., \& Van Caneghem, J. (2020). Characterization of poultry litter ash in view of its valorization. Waste and Biomass Valorization, 11, 5333-5348. https://doi.org/10.1007/s12649-019-00750-6

19. Coutand, M., Cyr, M., Deydier, E., Guilet, R., \& Clastres, P. (2008). Characteristics of industrial and laboratory meat and bone meal ashes and their potential applications. Journal of Hazardous Materials, 150(3), $522-532$. https://doi.org/10.1016/j.jhazmat.2007.04.133

20. Deydier, E., Guilet, R., Sarda, S., \& Sharrock, P. (2005). Physical and chemical characterisation of crude meat and bone meal combustion residue: "Waste or raw material?" Journal of Hazardous Materials, 121(1-3), 141-148. https://doi.org/10.1016/j.jhazmat.2005.02.003

21. Cohen, Y. (2009). Phosphorus dissolution from ash of incinerated sewage sludge and animal carcasses using sulphuric acid. Environmental Technology, 30(11), 1215-1226. https://doi.org/10.1080/09593330903213879 
22. Fang, L., Li, J., Guo, M. Z., Cheeseman, C. R., Tsang, D. C. W., Donatello, S., \& Poon, C. S. (2018). Phosphorus recovery and leaching of trace elements from incinerated sewage sludge ash (ISSA). Chemosphere, 193, $278-287$. https://doi.org/10.1016/j.chemosphere.2017.11.023

23. Sarabèr, A. J. (2014). Co-combustion and its impact on fly ash quality; Full-scale experiments. Fuel Processing Technology, 128, 68-82. https://doi.org/10.1016/j.fuproc.2014.06.026

24. European Sustainable Phosphorus Platform (ESPP). (2019). ESPP phosphorus fact sheet. Retrieved from https://phosphorusplatform.eu/images/download/ESPP-Phosphorus-fact-sheet-v21-4-19.pdf

25. Donatello, S., Tong, D., \& Cheeseman, C. R. (2010). Production of technical grade phosphoric acid from incinerator sewage sludge ash (ISSA). Waste Management, 30(8-9), 1634-1642. https://doi.org/10.1016/j.wasman.2010.04.009

26. Kaikake, K., Sekito, T., \& Dote, Y. (2009). Phosphate recovery from phosphorus-rich solution obtained from chicken manure incineration ash. Waste Management, $1084-1088$. https://doi.org/10.1016/j.wasman.2008.09.008

27. Ekpo, U., Ross, A. B., Camargo-Valero, M. A., \& Fletcher, L. A. (2016). Influence of pH on hydrothermal treatment of swine manure: Impact on extraction of nitrogen and phosphorus in process water. Bioresource Technology, 214, 637-644. https://doi.org/10.1016/j.biortech.2016.05.012

28. Petzet, S., Peplinski, B., \& Cornel, P. (2012). On wet chemical phosphorus recovery from sewage sludge ash by acidic or alkaline leaching and an optimized combination of both. Water Research, 46(12), 3769-3780. https://doi.org/10.1016/j.watres.2012.03.068

29. Darwish, M., Aris, A., Puteh, M. H., Jusoh, M. N. H., \& Kadir, A. A. (2017). Waste bones ash as an alternative source of $\mathrm{P}$ for struvite precipitation. Journal of Environmental Management, 203(2), 861-866. https://doi.org/10.1016/j.jenvman.2016.02.033

30. Franz, M. (2008). Phosphate fertilizer from sewage sludge ash (SSA). Waste Management, 28(10), $1809-1818$. https://doi.org/10.1016/j.wasman.2007.08.011

31. Schaum, C., Cornel, P., \& Jardin, N. (2007). Phosphorus recovery from sewage sludge ash - A wet chemical approach. In Proceeding of the IWA Conference (pp. 583-590). June 24-27, Moncton, Canada.

32. Xu, H., He, P., Gu, W., Wang, G., \& Shao, L. (2012). Recovery of phosphorus as struvite from sewage sludge ash. Journal of Environmental Sciences, 24(8), 1533-1538. https://doi.org/10.1016/S1001-0742(11)60969-8

33. Bogush, A. A., Stegemann, J. A., Williams, R., \& Wood, I. G. (2018). Element speciation in UK biomass power plant residues based on composition, mineralogy, microstructure and leaching. Fuel, 211, 712-725. https://doi.org/10.1016/j.fuel.2017.09.103

34. Kratz, S., Vogel, C., \& Adam, C. (2019). Agronomic performance of P recycling fertilizers and methods to predict it: A review. Nutrient Cycling in Agroecosystems, 115, 1-39. https://doi.org/10.1007/s10705-019-10010-7

35. EMIS. (2016). CMA/2/II/A.3: Ontsluitingsmethode voor de bepaling van elementen in bodem, vaste en pasteuze materialen. Belgisch Staatsblad.

36. European Committee for Standardization. (2002). EN 13656:2002 Characterization of waste - Microwave assisted digestion with hydrofluoric $(\mathrm{HF})$, nitric $(\mathrm{HNO} 3)$ and hydrochloric $(\mathrm{HCl})$ acid mixture for subsequent determination of elements.

37. Azuara, M., Kersten, S. R. A., \& Kootstra, A. M. J. (2013). Recycling phosphorus by fast pyrolysis of pig manure: Concentration and extraction of phosphorus combined with formation of value-added pyrolysis products. Biomass and Bioenergy, 49, 171-180. https://doi.org/10.1016/j.biombioe.2012.12.010

38. Luyckx, L. (2016). Fosforherwinning uit pluimveemestverbrandingsassen en uit beendermeel.

39. Wang, Q., Li, J., Tang, P., Fang, L., \& Poon, C. S. (2018). Sustainable reclamation of phosphorus from incinerated sewage sludge ash as value-added struvite by chemical extraction, purification and crystallization. Journal of Cleaner Production, 181, 717-725. https://doi.org/10.1016/j.jclepro.2018.01.254

40. Biswas, B. K., Inoue, K., Harada, H., Ohto, K., \& Kawakita, H. (2009). Leaching of phosphorus from incinerated sewage sludge ash by means of acid extraction followed by adsorption on orange waste gel. Journal of Environmental Sciences, 21(12), 1753-1760. https://doi.org/10.1016/S1001-0742(08)62484-5

41. Li, J., Chen, Z., Wang, Q., Fang, L., Xue, Q., Cheeseman, C. R., ... Poon, C. S. (2018). Change in re-use value of incinerated sewage sludge ash due to chemical extraction of phosphorus. Waste Management, 74, 404-412. https://doi.org/10.1016/j.wasman.2018.01.007

42. Szögi, A. A., Vanotti, M. B., \& Hunt, P. G. (2015). Phosphorus recovery from pig manure solids prior to land application. Journal of Environmental Management, 157, 1-7. https://doi.org/10.1016/j.jenvman.2015.04.010

43. VLAREMA - Besluit van de Vlaamse Regering tot vaststelling van het Vlaams reglement betreffende het duurzaam beheer van materiaalkringlopen en afvalstoffen. (2018). Retrieved from https://navigator.emis.vito.be/mijnnavigator?woId=43991

44. Kabbe, C., \& Rinck-Pfieffer, S. (2019). Global compendium on phosphorus recovery from sewage/sludge/ash.

45. European Sustainable Phosphorus Platform (ESPP), German Phosphorus Platform (DPP), \& Netherlands Nutrient Platform (NNP). (2020). Phosphorus recovery technology catalogue. Retrieved from 
https://phosphorusplatform.eu/images/download/ESPP-NNP-DPP_P-recovery_tech_catalogue_v_25_2_2020.pdf

46. Lee, M., \& Kim, D.-J. (2017). Identification of phosphorus forms in sewage sludge ash during acid pre-treatment for phosphorus recovery by chemical fractionation and spectroscopy. Journal of Industrial and Engineering Chemistry, 51, 64-70. https://doi.org/10.1016/j.jiec.2017.02.013

47. Fang, L., Li, J., Donatello, S., Cheeseman, C. R., Wang, Q., Poon, C. S., \& Tsang, D. C. W. (2018). Recovery of phosphorus from incinerated sewage sludge ash by combined two-step extraction and selective precipitation. Chemical Engineering Journal, 348, 74-83. https://doi.org/10.1016/j.cej.2018.04.201

48. Li, J., Tsang, D. C. W., Wang, Q., Fang, L., Xue, Q., \& Poon, C. S. (2017). Fate of metals before and after chemical extraction of incinerated sewage sludge ash. Chemosphere, 186, 350-359. https://doi.org/10.1016/j.chemosphere.2017.08.012

49. Liu, J., Li, K., Wang, H., Zhu, M., Xu, H., \& Yan, H. (2005). Self-assembly of hydroxyapatite nanostructures by microwave irradiation. Nanotechnology, 16, 82-87. https://doi.org/10.1088/0957-4484/16/1/017

50. Peplinski, B., Adam, C., Michaelis, M., Kley, G., Emmerling, F., \& Simon, F.-G. (2009). Reaction sequences in the thermochemical treatment of sewage sludge ashes revealed by X-ray powder diffraction - A contribution to the European project SUSAN. In Zeitschrift für Kristallographie Supplemente (Vol. 30, pp. 459-464). September 1922, Warsaw, Poland. https://doi.org/10.1524/zksu.2009.0068

51. Harvey, D. (2020). Complexation titrations. Retrieved May 15, 2020, from https://chem.libretexts.org/Bookshelves/Analytical_Chemistry/Book\%3A_Analytical_Chemistry_2.1_(Harvey)/09 \%3A_Titrimetric_Methods/9.03\%3A_Complexation_Titrations

52. Deutsche Forschungsgemeinschaft (DFG). (2014). Nitrilotriacetic acid and its sodium salts. In The MAK-collection for occupational health and safety. Wiley. https://doi.org/10.1002/3527600418.mb13913vere4514

53. Nowak, B., Aschenbrenner, P., \& Winter, F. (2013). Heavy metal removal from sewage sludge ash and municipal solid waste fly ash - A comparison. Fuel Processing Technology, 105, $195-201$. https://doi.org/10.1016/j.fuproc.2011.06.027

54. Liu, J., Fu, J., Ning, X., Sun, S., Wang, Y., Xie, W., ... Zhong, S. (2015). An experimental and thermodynamic equilibrium investigation of the $\mathrm{Pb}, \mathrm{Zn}, \mathrm{Cr}, \mathrm{Cu}, \mathrm{Mn}$ and $\mathrm{Ni}$ partitioning during sewage sludge incineration. Journal of Environmental Sciences, 35, 43-54. https://doi.org/10.1016/j.jes.2015.01.027

55. Li, J., Xue, Q., Fang, L., \& Poon, C. S. (2017). Characteristics and metal leachability of incinerated sewage sludge ash and air pollution control residues from Hong Kong evaluated by different methods. Waste Management, 64, 161-170. https://doi.org/10.1016/j.wasman.2017.03.033

56. Zhang, Y., Cetin, B., Likos, W. J., \& Edil, T. B. (2016). Impacts of pH on leaching potential of elements from MSW incineration fly ash. Fuel, 184, 815-825. https://doi.org/10.1016/j.fuel.2016.07.089

57. Yang, T., Rao, S., Zhang, D., Wen, J., Liu, W., Chen, L., \& Zhang, X. (2016). Leaching of low grade zinc oxide ores in nitrilotriacetic acid solutions. Hydrometallurgy, 161, $107-111$. https://doi.org/10.1016/j.hydromet.2016.01.024

58. Chembid. (n.d.). Prices for chemicals from different suppliers. Retrieved May 4, 2020, from https://www.chembid.com 